\title{
Self-Concept in Gifted Children: Differential Impact in Boys and Girls
}

\author{
Roger C. Loeb \\ University of Michlgan/Dearborn
}

\author{
Gina Jay \\ Pennsylvania State University
}

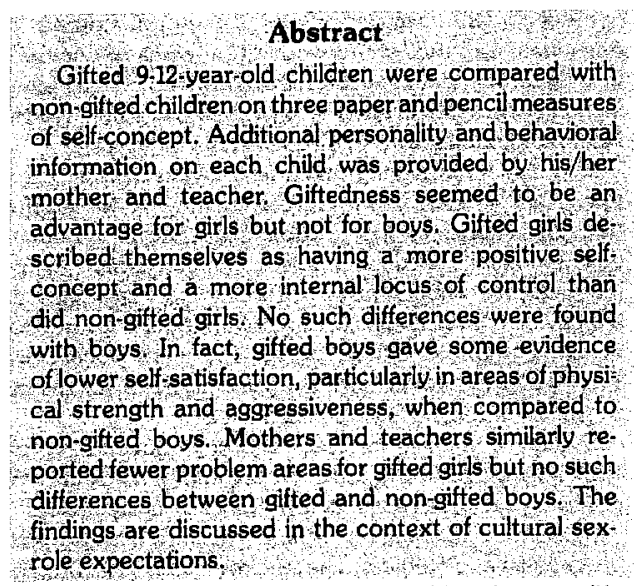

As academic programs for gifted children have proliferated in recent years, so have theoretical reports and research studies. Generally, this work has focused on student selection procedures, program development, and program evaluation. Most of these examinations have emphasized the cognitive sphere, but a growing body of literature has recognized the impact of social and personality factors on dealing with gifted children.

Perhaps the most commonly studied topic in this area is that of self-concept, probably because of its breadth as a personality descriptor as well as its exhaustively documented impact on other human characteristics including the cognitive. The recent literature provides a pattern of inconclusive findings. Many studies suggest that gitted children have better (more positive) self-concepts than non-gifted children (Colangelo \& Pfleger, 1978; Coleman \& Fults, 1982; Karnes \& Wherry, 1981; Kelly \& Colangelo, 1984; Lehman \& Erdwins, 1981; Maddux, Scheiber, \& Bass, 1982; O'Such, Twyla, \& Havertape, 1979). On the other hand, Trotter (1971) and Klein and Cantor (1976) reported that gifted individuals often had lower self-concepts than did their more typical peers, while no significant difference between the two groups on self-esteem was reported by Cantor, Klein, and Helfort (1979) and by Bracken (1980). Finally an extensive investigation of gifted high school students (Tidwell, 1980a) produced higher than average scores on one measure of self-esteem (the Piers-Harris) and lower on another (the Coopersmith).
These inconsistent results may have occurred due to differences among subject samples, (e.g., definitions of gifted), measures employed, and decisions concerning data analysis. Only recently have special measures been developed for the assessment of self-concept in gifted children (Feldhusen \& Koloff, 1981). Furthermore, many reports have failed to discuss (and perhaps not even statistically evaluate) sex differences. The few studies which have addressed gender differences provide varying results. Ross \& Parker (1980) reported that there were no sex differences in their study. On the other hand, Kelly and Colangelo (1984) found that in separate analyses by sex, higher self-concept scores held up only for males. Coleman and Fults (1982) found no significant sex differences, but they noted that gifted girls scored somewhat higher than gifted boys. Tangential support for these results came from a study of personal adjustment in college students (Tomlinson-Keasy \& SmithWinberry, 1983). This study found gifted women to be higher in personal adjustment than control women, while the reverse was true for males.

While the breadth of the self-concept measure makes it an attractive means for assessing overall personality functioning, it also limits us to global generalizations about personality. Recently, several researchers have attempted to gain greater specificity by distinguishing academic selfconcept from social self-concept. Ross and Parker (1980) reported lower expectations for success in social versus academic endeavors in a gifted sample, whereas Kelly and Colangelo (1984) found no such differences. Though at present the data are inconclusive, the need for such finer discriminations is evident if useful implications are to be drawn from the self-concept literature. More precise measurement may also help account for the divergent findings described above.

Locus of control is such a related, narrow self-concept measure. Studies have found the gifted to be relatively internal in locus of control; i.e., perceive themselves as having control over the reinforcements in their own lives (Fincham \& Barling, 1978; Hontz, Denmark, Rosenfield \& Tetenbaum, 1980; Tidwell, 1980b). Thus, locus of control appears to be worthy of additional investigation within the context of self-concept in gifted children.

Another measure of self-concept is how satisfied a person is with him or herself. Powell (1982) has suggested that the gifted have a high potential for self-inflicted misery resulting from the discrepancy between the ideal self for which they strive and the real self which they achieve. This theory 
can be assessed directly by means of a Q-Sort technique (Stephenson, 1953).

The self-concept literature is replete with studies employing self-report questionnaires; far fewer in number are studies which have employed either behavioral observations or parent/teacher ratings. One study did use teacher ratings (Ludwig \& Cullinan, 1984) and found gifted students to be slightly lower in frequency of behavior problems. The personality traits of parents of gifted children have been studied (Fell, Dahlstron, \& Winter, 1984), but their roles as parents of gifted children have been treated superficially according to Colangelo and Dettman (1983).

In summary, the existing literature fails to provide clearly differentiated measures of self-concept, has not adequately studied certain key subject variables (especially gender), and has generally relied solely on self-report measures. In contrast, the present study uses a multi-method approach including three self-report measures of various aspects of self-concept, as well as both mother and teacher ratings.

\section{Methods}

\section{Subjects}

The subjects were 227 children between 9 and 12 years of age $(\bar{X}=10.72)$ from the schools in three predominantly white, middle-class suburbs. All students enrolled in fourth through sixth grade gifted programs of the three school districts were eligible to participate. These gifted programs selected the students based on scores on standardized aptitude and achievement tests and teachers' recommendations. Two of the programs are full time, while students in the third are partially mainstreamed. The three school districts provided 125 (60 male, 65 female) gifted students. Control subjects (non-gifted) were selected from the regular classes in the same schools and provided 102 (46 male, 56 female) students.

\section{Procedure}

Two experimenters conducted each testing session. Each child took part in a small group administration (2-15 children) of the two personality scales, while the remainder of the procedure was conducted individually. All testing took place at the children's schools.

The group testing procedure began with a shortened form of the Nowicki-Strickiand Children's Locus of Control Scale (Nowicki \& Strickland, 1973). This scale consists of 19 yes/no items each of which has an internal and external response from which the respondent makes a choice. The total number of external responses is calculated to determine a locus of control score which can range fro 0 to 19 . A higher score reflects a more external locus of control (subject feels that he/she does not control the reinforcements in his/her life), while a lower score reflects a more internal locus of control (a greater feeling of control over the reinforcements in his/her life.)

All subjects then completed the Piers-Harris Children's
Self-Concept Scale (Piers \& Harris, 1964) which provides a general measure of self-esteem as well as cluster scores on six components of self-concept (behavior, intellectual, physical, anxiety, popularity, and happiness) (Piers, 1969). This inventory consists of 80 statements to which the subjects indicate whether each item describes how they feel about themselves. Scores can range from 0 to 80 , with higher scores reflecting a more positive self-concept.

Subjects were regularly asked if they understood the questions, and they were watched for signs of confusion or fatigue. Standardized alternative forms of all questions, including concrete examples, were available when needed. Brief rest periods were also provided as necessary.

The individual testing procedure began with a Q-Sort task which was used to provide a measure of self-satisfaction. This task required the child to sort 15 cards containing descriptions of human characteristics (e.g., smart, happy) into five piles ranging from "most like" to "least like" self (Actual Sort). The subjects repeated this card sorting task describing next how they "would like to be" (Ideal Sort). The greater the Actual Sort-Ideal Sort discrepancy, the less satisfied the subject is with him/herself.

Testing took 35-45 minutes varying by how quickly the child responded to the tasks. At the end of all testing, the children were given stickers as a token of appreciation.

Personality and behavioral information was also provided by teachers and mothers. The teachers rated their students using a five-point scale from no problems (1) to a lot of problems (5) on seven potential problem areas for children (e.g., shyness). Mothers provided both demographic (e.g., child's birth order) and historical (e.g., past educational problems) information, as well as ratings much like those of the teachers. They also described their childrearing strategies by marking an " $\mathrm{X}$ " along continua on four parenting options; i.e., help child vs. encourage independence, permissive vs. strict, rely on physical communication us. verbal communication, and stress obedience vs. independence. A total of 210 mothers (92\%) participated in this phase of the study.

\section{Results}

It should first be noted that the gifted and the non-gifted samples did not significantly differ in family size, child's birth order, number of parents in the home, parents' marital status, or maternal employment. There were also no differences based on age of subjects or on school district (type of gifted program).

All dependent variables were analyzed in two-way (gifted versus non-gifted, male versus female) analyses of variance. The teachers of gifted students generally rated them as having fewer problems in almost all areas than did the teachers of the control students (See Table 1). Control subjects were more often reported as having problems with aggressiveness, depression, lack of confidence, school work, getting along with other children, and getting along 
with adults. These individual items should be interpreted cautiously as they are not independent measures. It is the pattern of results that is most meaningful.

While there were no main effects for gender, significant classroom placement by gender interaction effects for both confidence and school work reflected the fact that the gifted only had substantialiy fewer problems in these areas if they happened to be female. Furthermore, in comparing means (t-tests) for males and females separately, all six of the problem areas were significantly lower (less problematic) for gifted girls (See Table 2). Only one (getting along with adults) was significantly lower for gifted boys.

Fewer differences between gifted and control subjects were reported by mothers than by teachers, but the pattern was consistent (See Table 3). Mothers of gifted children less frequently reported educational or learning problems among their children than did the mothers of control children. There was also a significant interaction effect for aggressiveness which resulted from gifted boys having fewer aggressive problems while gifted girls had slightly more.

On approaches to child rearing, two of the four topics resulted in significant differences (See Table 3 ). Mothers of gifted children reported relying relatively more on verbal communication like talking, while mothers of control children more often reported using physical communication techniques such as touching. Mothers of the gifted also claimed to place more emphasis on independence, while mothers of controls claimed to place greater emphasis on obedience. On both variables the differences are greater for girls than for boys.

On the children's self ratings, there were no significant main effects or interaction effects on the measures of selfconcept (Piers-Harris), locus of control (Nowickj-Strick-

Table 1

Teachers' Ratings of Student Problems Among Gifted and Controls: Means and $F$ Values for Classroom Main Effect and Classraom by Gender Intervention Effect

\begin{tabular}{|c|c|c|c|c|}
\hline Problem & Gifted & Controls & $\begin{array}{c}\text { Classroom } \\
\text { Main Effect (F) }\end{array}$ & $\begin{array}{l}\text { Interaction } \\
\text { Effect }(\mathrm{F})\end{array}$ \\
\hline Shyness & 2.00 & 2.04 & 0.06 & 1.52 \\
\hline Aggressiveness & 1.60 & 2.01 & $7.28^{* \star}$ & 0.00 \\
\hline Depression & 1.34 & 1.63 & $7.35^{* \star}$ & 3.46 \\
\hline Nervousness & 1.89 & 1.96 & 0.28 & 0.27 \\
\hline $\begin{array}{l}\text { Getting along with } \\
\text { other children }\end{array}$ & 1.65 & 1.97 & $5.10^{*}$ & 0.17 \\
\hline $\begin{array}{c}\text { Getting aiong } \\
\text { with adults }\end{array}$ & 1.35 & 1.76 & $14.16^{* *}$ & 0.52 \\
\hline Lack of confidence & 1.77 & 2.13 & $8.44^{* *}$ & $6.06^{*}$ \\
\hline School work & 1.55 & 2.31 & $24.79^{\star \star}$ & $4.71^{\star}$ \\
\hline
\end{tabular}

Table 2

Teachers' Ratings of Student Problems Among Gifted and Controls: Means, Standard Deviations, and t Values Reported Separately by Gender

\begin{tabular}{|c|c|c|c|c|}
\hline & Sex & $\begin{array}{c}\text { Gifted } \\
\text { Means } \\
\text { (Standard } \\
\text { Deviations) }\end{array}$ & $\begin{array}{l}\text { Control } \\
\text { Means } \\
\text { (Standard } \\
\text { Deviations) }\end{array}$ & $\mathrm{t}$ \\
\hline Shyness & $\begin{array}{l}\text { Girls } \\
\text { Bays }\end{array}$ & $\begin{array}{l}2.03(0.90) \\
1.95(0.96)\end{array}$ & $\begin{array}{l}2.22(1.12) \\
1.85(0.94)\end{array}$ & $\begin{array}{r}-1.02 \\
0.55\end{array}$ \\
\hline Aggressiveness & $\begin{array}{l}\text { Girls } \\
\text { Boys }\end{array}$ & $\begin{array}{l}1.45(0.94) \\
1.78(1.09)\end{array}$ & $\begin{array}{l}1.87(1.32) \\
2.15(1.21)\end{array}$ & $\begin{array}{l}-2.06^{\star} \\
-1.65\end{array}$ \\
\hline Depression & $\begin{array}{l}\text { Girls } \\
\text { Boys }\end{array}$ & $\begin{array}{l}1.36(0.76) \\
1.37(0.66)\end{array}$ & $\begin{array}{l}1.80(1.00) \\
1.43(0.69)\end{array}$ & $\begin{array}{l}-2.69^{* *} \\
-0.52\end{array}$ \\
\hline Nervousness & $\begin{array}{l}\text { Girls } \\
\text { Boys }\end{array}$ & $\begin{array}{l}1.87(0.79) \\
1.92(0.70)\end{array}$ & $\begin{array}{l}2.00(1.12) \\
1.91(1.15)\end{array}$ & $\begin{array}{r}-0.71 \\
0.02\end{array}$ \\
\hline $\begin{array}{l}\text { Getting along } \\
\text { w/other children }\end{array}$ & $\begin{array}{l}\text { Girls } \\
\text { Boys }\end{array}$ & $\begin{array}{l}1.53(0.97) \\
1.76(0.97)\end{array}$ & $\begin{array}{l}1.94(1.11) \\
2.02(1.16)\end{array}$ & $\begin{array}{l}-2.16^{\star} \\
-1.24\end{array}$ \\
\hline $\begin{array}{l}\text { Getting along } \\
\text { w/adults }\end{array}$ & $\begin{array}{l}\text { Girls } \\
\text { Boys }\end{array}$ & $\begin{array}{l}1.23(0.56) \\
1.47(0.87)\end{array}$ & $\begin{array}{l}1.76(0.98) \\
1.80(0.86)\end{array}$ & $\begin{array}{l}-3.68^{* * *} \\
-1.99^{*}\end{array}$ \\
\hline $\begin{array}{l}\text { Lack of } \\
\text { Confidence }\end{array}$ & $\begin{array}{l}\text { Girls } \\
\text { Boys }\end{array}$ & $\begin{array}{l}1.81(0.85) \\
1.77(0.77)\end{array}$ & $\begin{array}{l}2.42(1.07) \\
1.80(0.92)\end{array}$ & $\begin{array}{l}-3.45^{* \ldots *} \\
-0.20\end{array}$ \\
\hline School work & $\begin{array}{l}\text { Girls } \\
\text { Boys }\end{array}$ & $\begin{array}{l}1.37(0.78) \\
1.77(1.06)\end{array}$ & $\begin{array}{l}2.43(0.7 B) \\
2.17(1.20)\end{array}$ & $\begin{array}{l}-4.93^{k \hbar k} \\
-1.85\end{array}$ \\
\hline
\end{tabular}

Table 3

Means and F Values of Mothers' Ratings of Their Children's Problems and of Their Child Rearing Approaches With Gifted and Controls

\begin{tabular}{|c|c|c|c|c|c|}
\hline $\begin{array}{l}\text { Children's } \\
\text { Problems }\end{array}$ & $\operatorname{Sex}$ & Gitted & Controls & $\begin{array}{l}\text { Subject } \\
\text { Group } \\
\text { Main } \\
\text { Effect } \\
\text { (F) }\end{array}$ & $\begin{array}{l}\text { Gender by } \\
\text { Subject } \\
\text { Group } \\
\text { Interaction } \\
\text { Effect } \\
\text { (F) }\end{array}$ \\
\hline $\begin{array}{l}\text { Educational } \\
\text { problems }\end{array}$ & $\begin{array}{l}\text { Girls } \\
\text { Boys }\end{array}$ & $\begin{array}{l}1.02 \\
1.02\end{array}$ & $\begin{array}{l}1.10 \\
1.13\end{array}$ & $7.71^{\star \star \star}$ & 0.08 \\
\hline Aggressiveness & $\begin{array}{l}\text { Girls } \\
\text { Boys }\end{array}$ & $\begin{array}{l}1.80 \\
1.62\end{array}$ & $\begin{array}{l}1.71 \\
2.18\end{array}$ & 1.50 & $3.80^{*}$ \\
\hline $\begin{array}{l}\text { Child Rearing } \\
\text { Approach }\end{array}$ & & Gifted & Controls & $F$ & \\
\hline $\begin{array}{l}\text { Verbal us. } \\
\text { physical } \\
\text { communication }\end{array}$ & $\begin{array}{l}\text { Girls } \\
\text { Boys } \\
\text { Combined }\end{array}$ & $\begin{array}{l}3.92 \\
3.89 \\
3.91\end{array}$ & $\begin{array}{l}3.42 \\
3.54 \\
3.48\end{array}$ & $\begin{array}{l}4.64^{\star} \\
1.71 \\
6.27^{\star *}\end{array}$ & \\
\hline $\begin{array}{l}\text { Independence } \\
\text { vs. obedience }\end{array}$ & $\begin{array}{l}\text { Girls } \\
\text { Boys } \\
\text { Combined }\end{array}$ & $\begin{array}{l}4.65 \\
4.40 \\
4.53\end{array}$ & $\begin{array}{l}3.85 \\
3.84 \\
3.85\end{array}$ & $\begin{array}{l}8.08^{\star \star} \\
4.90^{\star} \\
12.17^{\star \star \star}\end{array}$ & \\
\hline $\begin{array}{l}\text { Girls d.f.: } 1,110 \\
\text { p }<.05\end{array}$ & $\begin{array}{l}\text { Boys d } \\
<.01\end{array}$ & 1,96 & 001 & d d.f.: 1, & 98 \\
\hline
\end{tabular}


land), or satisfaction with self (Q-Sort). Given the focus on sex differences, separate one-way analyses of variance (gifted vs. control) were performed for males and for females. The patterns of results were strikingly different for the two sexes (see Table 4). Gifted girls proved to have a better (higher) self-concept than control girls on the Piers-Harris scale. This difference resulted from more positive self-concept responses from gifted girls on such items as being smart, being good at making things with their hands, not doing bad things, not getting into trouble, and not forgetting what they had learned. There were no such group differences for boys.

Gifted giris also scored more internal (a lower number) in locus of control than control girls, whereas there was no significant difference between the two groups of boys. Several of these items dealt with physical strength; i.e., gifted girls more frequently described themselves as strong whereas gifted boys did not often report a self-image of strength. Gifted boys also described themselves as less satisfied with themselves than the control boys, based on the higher difference beteen their actual and their ideal scores on the Q-sort. For example, gifted boys saw themselves as much less helpful than they would like to be, while control boys placed their actual ranking of helpfulness at about the same ranking as their ideal.

\section{Discussion}

The impact of giftedness on children can apparently best be understood in the context of the children's gender. In American society, being identified as a "gifted" child (operationally defined as successful on cognitive tests and classroom performance as well as being in an explicitlydefined gifted program) means one thing for pre-teen girls and quite another for pre-teen boys. For girls, classroom success appears to be congruent with a positive self-image. The traditional feminine ideal seems to involve being wellbehaved, conscientious, and obedient. Academic success, as well as high scores on standardized mental tests, may

\section{Table 4}

Means, Standard Deviations, and $F$ Values on Self-report Scores for Gifted and Control Girls and Boys

\begin{tabular}{|c|c|c|c|c|c|c|}
\hline \multirow{2}{*}{$\frac{\text { Measure }}{\text { Piers-Harris }}$} & \multirow{2}{*}{$\begin{array}{l}\text { Sex } \\
\text { Girls } \\
\text { Boys }\end{array}$} & \multicolumn{2}{|c|}{$\begin{array}{c}\text { Gifted } \\
(\mathrm{n}=125) \\
\text { Means } \\
\text { (Standard } \\
\text { Deviations) }\end{array}$} & \multicolumn{2}{|c|}{$\begin{array}{c}\text { Controls } \\
\text { (n=102) } \\
\text { Means } \\
\text { (Standard } \\
\text { Deviations) }\end{array}$} & \multirow{2}{*}{ 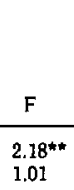 } \\
\hline & & $\begin{array}{l}62.72 \\
61.25\end{array}$ & $\begin{array}{r}(9.30) \\
(11.83)\end{array}$ & $\begin{array}{l}59.11 \\
61.17\end{array}$ & $\begin{array}{l}(13.73) \\
(11.76)\end{array}$ & \\
\hline $\begin{array}{l}\text { Nowicki- } \\
\text { Strickland }\end{array}$ & $\begin{array}{l}\text { Girls } \\
\text { Boys }\end{array}$ & $\begin{array}{l}5.89 \\
6.38\end{array}$ & $\begin{array}{l}(2.23) \\
(2.72)\end{array}$ & $\begin{array}{l}6.93 \\
6.63\end{array}$ & $\begin{array}{l}(2.69) \\
(2.42)\end{array}$ & $\begin{array}{l}1.95^{\star} \\
1.27\end{array}$ \\
\hline Q-Sort & $\begin{array}{l}\text { Girls } \\
\text { Boys }\end{array}$ & $\begin{array}{l}12.03 \\
12.93\end{array}$ & $\begin{array}{l}(4.76) \\
(5.58)\end{array}$ & $\begin{array}{l}13.00 \\
12.00\end{array}$ & $\begin{array}{l}(5.45) \\
(3.89)\end{array}$ & $\begin{array}{l}1.31 \\
2.06^{*}\end{array}$ \\
\hline
\end{tabular}

ensue from the need for "achievement through conformance" associated with this traditional female personality profile, at least in the elementary grades. Thus, the achieving young female develops a positive sense of self and feelings of control over her life space. This conclusion may be related to the higher verbal fluency generally associated with young females. Verbal fluency in children is reportedly associated with an internal locus of control and positive self-esteem according to Hontz, et al. (1980). Additionally, the effect may simultaneously work in the opposite direction; i.e., a positive self-concept aids and encourages the girls in their efforts towards academic excellence.

It is quite a different picture for the traditional ideal male. $\mathrm{He}$ is aggressive, self-reliant, and individualistic, a pattern more often associated with "achievement via independence" (See Gough, 1964, for discussion of the two types of achievement orientation). While such an inteilectual orientation may serve him well at a later stage of educa. tional training, it is one ill-suited for the elementary grades. There is evidence that the predominance of female teachers at these levels contributes to the perception of early edu. cation as "feminized" (see Loeb \& Horst, 1978). Thus, academic success, and particularly when it results in being labeled "gifted", may foster feelings of self-doubt, weakness; and lack of control in the young boy.

This gender pattern appears to undergo a shift during adolescence. High schools may be more supportive of the masculine achievement style than elementary schools. The positive ties between early education and femininity may reverse themselves during adolescence when girls are confronted by conflicts between their identity as gifted students and their emerging identity as women (Rodenstein, Pfleger, \& Colangelo, 1977). Gifted adolescent female students who were analytic and who preferred original to conventional approaches (considered unfeminine orientations) were given very low ratings by their teachers (Welsh, 1977). This developmental shift may account for the Kelly and Colangelo (1984) results which found giftedness more problematic for females than males in an adolescent sample (see also Blaubergs, 1980). That age may be an interacting variable with gender differences among the gifted has been suggested by Callahan (1980).

The negative image of the bookish, young boy is further supported in the present study by the one finding at odds . with the overall negative pattern for gifted boys, namely aggression. According to both mothers and teachers, gifted boys had fewer problems with aggressiveness than did control boys. Gifted boys were also more likely to see themselves as external in locus of control concerning issues of physical power than were non-gifted boys. Thus, even the gifted boys" "advantage" of fewer problems in aggressiveness can be seen as a failure to measure up to the masculine image. Such sex-role expectations and their interactions with being gifted reflect the impact of peers and its growing import as the child matures. The role of peers 
indetermining standards of acceptability and/or desirability of child behaviors should not be underestimated.

Assuming our society values and wishes to foster both giftedness and positive self-concept, what changes should be considered based on the present findings? Apparently changes are most needed in dealing with gifted males and non-gifted females, at least in this pre-adolescent period. The first set of changes for the gifted males involves the defeminization of early education: more male teachers in the elementary grades (intellectual role models), more tolerance for independent thought and behavior in elementary classrooms, and inclusion of more traditionally masculine interests (e.g., mechanics, outer space) in teachers' presentations. Indirect support for such recommendations comes from a study by Flesher and Pressey (1955) which reported improved achievement in accelerated mathematics among girls if the classes were taught by women.

Secondly, efforts need to be made in the direction of positive evaluation of pre-teen boys for early academic success. Parents and educators need to lead the way to a new definition of the masculine ideal which would encompass academic striving and academic excellence in the elementary school years. Ford (1978) found that middle-school gifted students (boys and girls) wanted to be in gifted programs, but only if it did not lead to conflict with peers. Negative peer pressure is likely to be felt by boys unless such programs can become part of a successful male image.

Third, while gifted pre-adolescent females appear to have satisfactory self-perceptions, it is important not to overlook the difficulties of the non-gifted girls. Attention from parents and teachers must be given to such girls in order to avoid the negative cycle of less than excellent academic performance producing a poor self image followed by poorer school performance, etc. The strengths and positive attributes of females not described as gifted must be valued and explicitly appreciated if society is to receive and to promote maximal behaviors and attitudes for all of its women and its men.

Finally, the findings that mothers of gifted children describe their child-rearing approaches differently from mothers of non-gifted (relying more on verbal than physical mode and emphasizing independence over obedience) suggests that such styles may encourage academic success. A widely-cited study on families of gifted (Getzels and Jackson, 1962) similarly described fathers of the gifted as more permissive than fathers in other families. While these studies imply that such parental behaviors foster or, at least, encourage giftedness, it should be noted that the direction of effect may work in the opposite direction as well. That is, gifted children may be more verbal and more amenabie to verbal communication as well as more able to behave successfully in an independent fashion, compared to the non-gifted children. Thus gifted children may modify their parents' behavior as well as parental behaviors impacting on the potential for giftedness in their children.

\section{References}

Blaubergs, M.5. (1980). Sex-role stereotyping and gifted girls. Roeper Review, 2 (3), 13-15.

Bracken, B. A. (1980). Comparison of self-attitudes of gifted children and childrer in a nongifted normative group. Psychological Reports, 47 (3), (pt. 1), 715-718.

Callahan, C. M. (1980). The gifted girl: An anomaly? Roeper Review, 2 (3), 16-20.

Cantor, C. L., Klein, P. S., \& Helfort, L. (1979). A brief affective education intervention with gifted and non-gifted children. Creative Child and Adult Quarterly, 4 (2), 81-86.

Colangelo, N., \& Dettman, D. F. (1983). A review of research on parents and famillies of gifted children. Exceptional Children, 50 (1), 20-27.

Colangelo, N., \& Pfleger, L R. (1978). Academic self-conçept of gifted high school students. Roeper Review, 1, 10-11.

Coleman, J. M., \& Fults, B. A. (1982), Self-concept and the gifted classroom: The role of social comparison. Gifted Child Quarterly, 26 (3), 116-120.

Fell, L., Dahistrom, M., \& Winter, D. C. (1984). Personality traits of parents of gifted children. Psychological Reports, 54 (2), 383-387.

Feldhusen, J. F., \& Kolloff, M. B. (1981). Me: A self-concept scale for gifted students. Perceptual and Motor Skilis, 53, 319-323.

Fincham, F., \& Barling, J. (1978). Locus of control and generosity in learning disabled, normal achieving, and gifted children. Child Development, 49, 530-533.

Flesher, M., \& Pressey, S. L. (1955). War-time accelerates ten years after. Joumal of Educational Psychology, 46, 228-238.

Ford, B. (1978). Student attitudes toward special programming and identification. Gifted Child Quarterly, 22 (4), 489-497.

Getzels, J. W., \& Jackson, P. W. (1962). Creativity and intelligence: Explaration with gifted students. New York: John Wiley.

Gough, H. E. (1964). Manual for the California Psychological Inventory. Palo Alto, CA: Consulting Psychologists Press.

Hontz, J. C., Denmark, R., Rosenfield, S., \& Tetenbaum, T. J. (1980). Probiem solving and personality characteristics related to differing levels of intelligence and ideational fluency. Contemporary Educotionol Psychology, $5(2), 118-123$.

Karnes, F. A., \& Wherry, J. N. (1981). Seli-concepts of gifted students as measured by the Piers-Harris Children's Self-Concept Scale. Psychological Reports, 49 (3), 903-906.

Kelly, K. R., \& Colangelo, N. (1984). Academic and social self-concepts of gifted, general, and special students. Exceptional Children, 50 (6), 551.554.

Klein, P. S., \& Cantor, L. (1976). Gitted children and their self-concept. Creative Child and Adult Quarteriy, 1, 98-101.

Lehman, E. B., \& Erdwins, C. J. (1981). The social and emotional adjustment of young, intellectually-gifted children. Gifted Child Quarterly, 25 (3), 134-137.

Loeb, R. C., \& Horst, L. (1978). Sex differences in self- and teachers' reports of self-esteem in preadolescents. Sex Roles, 4 (5), 779-788.

Ludwig, G., \& Cullinan, D. (1984). Behavior problems of gifted and non-gifted elementary school girls and boys. Gijted Child Quarteriy, 1984,28 (1), 37-39.

Maddux, C. D., Scheiber, L. M., \& Bass, J. E. (1982). Self-concept and social distance in gifted children. Gifted Child Quarterly, 26 (2), 77.81.

Nowicki, S., \& Strickland, B. R. (1973). A locus of control scale for children. Journal of Consulting and Clinical Psychology, 40, 148-155.

O'Such, K., Twyla, G., \& Havertape, J. (1979). Group differences in selfconcept among handicapped, normal, and gifted learners. The Humanistic Educator, 18, 15-22.

Piers, E. V. (1969). Manual for the Piers.Harris Children's Self-Concept Test. Nashville, TN: Counselor Recordings and Tests.

Piers, E. V., \& Harris, D. B. (1964). Age and other correlates of self-concept in children. Joumal of Educational Psychology, 55, 91-95.

Powell, P. M. (1982). "Seduction of ideas." Roeper Review, 3 (4), 3-4. 
Rodenstein, J., Pfleger, L., \& Colangelo, N. (1977). Career development needs of the gifted: Special considerations for gifted women. Gifted Child Quarterly, 20, 340-347.

Ross, A., \& Parker, M. (1980). Academic and social self-concepts of the academically gifted. Exceptional Children, 47 (1), 6-10.

Stephenson, W. (1953). The study of behavior: Q-Technique and its methodology. Chicago, IL: University of Chicago Press.

Tidwell, R. (1980a). A psycho-educational profile of 1,593 gifted high school students. Gifted Child Quarterly, 24, 63-68.
Tidwell, R. (1980b). Gifted students' self-images as a function of identification procedure, race, and sex. Journal of Pediatric Psychology, 5(1), 57-69.

Tomlinson-Keasey, C., \& Smith-Winberry, C. (1983). Educational strategies and personality outcomes of gifted and nongifted college students. Gifted Child Quarterly, 27 (1), 35-41

Trotter, R. (1971). Self-image. Science News, 100, 130-191.

Welsh, G. S. (1977). Personality correlates of intelligence and creativity in gifted adolescents. In J. C. Stanley, W. C. George, and C. H. Solano (Eds.), The gifted and the creative: A fifty-year perspective. Baltimore, MD: Johns Hopkins University Press.

\section{Study of Mathematically Precocious Youth 94th Percentile Groups}

SMPY announces the creation of a new national math-taient group for females, called " 640 690 on SAT-M Before Age 13." This is done in order to offer SMPY's eductional services to far more young women who reason extremely well mathematically than qualify for membership in SMPY's "700-800 on SAT-M Before Age 13" group. About 6 percent of college-bound female high-school seniors scored 640 or more on SAT-M during the 1984-85 school year, whereas about 6 percent of college-bound male high-school seniors scored 700 or more. Thus, 640 is the 94 th \% ile for females, and 700 is the 94 th \%ile for males. This 60 -point discrepancy causes about 12 times as many males as females to qualify for SMPY's "700-800 on SAT-M Before Age 13" group.

To become eligible for the new group, a female need only send us a copy of her SAT score report showing that, after 31 December 1985, she scored within the range 640 through 690 on or before her 13th birthday. If she scored $700 \mathrm{M}$ or more, she is eligible for membership in the $700-800 \mathrm{M}$ group, instead.
An older girl may also qualify for the $640-690 \mathrm{M}$ group by scoring 10 points above 640 for each month or fraction of a month beyond her 13th birthday. This means that she can qualify up to the day she becomes 14 years 4 months old, at which point she needs the highest attainable SAT-M score, 800 .

Fifteen percent of college-bound male highschool seniors score $640 \mathrm{M}$ or more. Therefore, by the upper $6 \%$ rule that defines the $640-690 \mathrm{M}$ group, males are ineligible for membership in that group.

This supplemental treatment of the two sexes according to percentile rank of score for one's sex is meant to provide SMPY an equal number of mathematically highly able males and females to help educationally. Thus, the " $640-690$ on SAT-M Before Age 13" group favors young women only to the extent that it redresses the numerical imbalance by sex long found in the "700-800 on SAT-M Group."

Address all correspondence to:

SMPY, Department of Psychology

The Johns Hopkins University

Baltimore, MD 21218. 